DIVISION OF THE HUMANITIES AND SOCIAL SCIENCES

CALIFORNIA INSTITUTE OF TECHNOLOGY

PASADENA, CALIFORNIA 91125

REGULATION, TAXATION, AND THE DEVELOPMENT OF THE GERMAN UNIVERSAL BANKING SYSTEM, 1884-1913

Caroline Fohlin

Forthcoming in European Review of Economic History

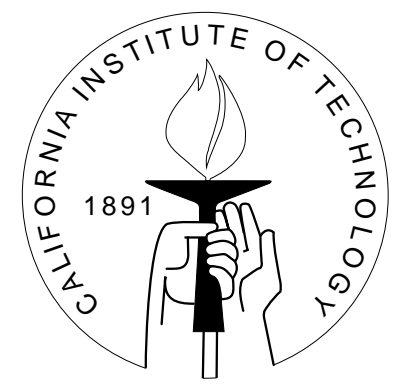

SOCIAL SCIENCE WORKING PAPER 1065R

February 2000

Revised May 2001 


\title{
Regulation, Taxation, and the Development of the German Universal Banking System, 1884-1913
}

\author{
CAROLINE FOHLIN \\ California Institute of Technology \\ Mailcode 228-77 \\ Pasadena, CA 91125 \\ fohlin@hss.caltech.edu
}

\begin{abstract}
Previous researchers argue that the legal and regulatory environment helped shape the German financial system in the nineteenth and early-twentieth centuries, with particular emphasis on the damaging effects of the stock-exchange law of 1896. This paper finds that the stock exchange law of 1896 exerted little measurable impact on the growth and concentration of the universal banking system or on the business turnover of universal banks relative to securities markets. The paper also shows that the English commercial banking sector and the German universal banking sector underwent similar movements toward concentration between 1884 and 1920 (both accelerating after 1912), despite no corresponding regulatory changes in England-further suggesting that consolidation of universal banking resulted from factors other than the 1896 law.
\end{abstract}




\section{Regulation, Taxation, and the Development of the German Universal Banking System, 1884-1913}

The historical literature has traditionally paid much attention to the role of universal banking in the industrialization of Germany and has presumed, in line with Gerschenkron (1962), that the system gained preeminence in the late nineteenth century due to the general 'backwardness' of the economy. Some researchers have stressed legal and political factors in the evolution of German financial institutions, placing particular emphasis on the Stock Exchange Law of 1896. ${ }^{1}$ The 1896 law, because it restricted the allowable activities of the securities exchanges, is seen as promoting the growth and concentration and possibly also monopoly power in the universal banking sector. Two important tax levies on securities market business, arriving shortly before and after the 1896 law, are also considered as an catalyst for change in the financial system. Despite the many claims made about the impact of regulation and taxation, though, a convincing quantitative analysis of the multiple influences is still lacking.

The current paper begins to fill this gap by examining company law and stock exchange regulations from the 1870s until the onset of World War I and by investigating the measurable effects of this legal framework on the development of the universal banking sector from 1884 to 1913 . The analysis covers three hypothesized areas of impact: concentration, overall growth, and volume of business relative to the stock markets. The findings indicate that the size and volume of the German universal banks developed in a strong, but sustained, manner throughout the period considered, and concentration of the sector increased less than the conventional wisdom supposes. None of the three considered indicators reacted significantly to the 1896 stock exchange law, but all three appear to have increased weakly in response to taxes. Comparison with the British deposit banking sector indicates that the two countries followed nearly identical paths towards increasing concentration between 1884 and 1920, and that indeed the greatest push towards concentration came between 1913 and 1920-long after the regulation and taxation episodes in Germany. Moreover, in spite of the growth of the German universal banking sector during the period, the British deposit banking sector was still markedly larger in 1913 (normalized by GNP). ${ }^{2}$ Thus, the evidence suggests that the effects of individual pieces of legislation were small compared to other changes in the economy.

The paper is organized as follows: the next section sets out the hypothesized impact of the legal changes between 1884 and 1913, focusing on the company law of 1884, the stock exchange law of 1896, 
and the tax laws of 1885,1894 , and 1900 . The third part tests these hypotheses empirically, first by examining the German case during 1884-1913 and then by extending the analysis to later years and to the British comparison. The final section concludes.

\section{The hypothesized impact of company law, exchange regulations, and tax measures}

Regulation and taxation of the German securities exchanges began primarily in the nineteenth century. The excesses of the early 1870's, the so-called Gründerjahre, and the bust that followed brought calls for reform: greater protection for shareholders and tighter restrictions on the stock exchanges. Company law, regulating the founding and governance of joint-stock firms, also changed over the last half of the nineteenth century. While the right to begin such an enterprise became almost universal by 1870 , the government retained a variety of controls over firms' organization, operation, and financing. Thus, given the natural interdependence of the stock markets and joint-stock companies, regulation and taxation of the two institutions was intimately linked.

The universal banking system constituted the third component of the German corporate finance triumvirate. Though the universal banks remained unregulated except by laws applying to all joint-stock companies, regulations and taxes on joint-stock companies and stock exchanges have been hypothesized by other researchers to have affected, both directly and indirectly, the operations of these banks. Indeed, it is plausible that tightening regulations on securities issues and trading while remaining permissive on the activities of universal banks might have encouraged growth in the universal banking sector at the expense of the exchanges.

The various regulations and tax measures enacted between 1880 and 1913 may have influenced the universal banking sector in a number of ways. Three such effects are commonly cited: propagating concentration in the universal banking industry, encouraging universal banks to expand operations, and pushing business from the securities exchanges into the largest universal banks. Table 1 lays out the important measures and economic events in chronological order along with their hypothesized impacts in the three areas of interest here. Organizing the regulatory history in this format underscores the rapid succession of potential stimuli as well as the indeterminacy of some influences. 


\subsection{Underwriting new issues and admission of shares to official trading}

The issuing of new securities in Germany proceeded primarily through the universal banks. Most flotations took place by simultaneous founding (Übernahmegründung), in which a promoter or underwriter took over the full amount of the issue and subsequently sold the shares to the public. Among other provisions, the 1870 company law, revised in the company law of 1884 , required the full amount of an issue to be subscribed and at least 25 percent to be paid up before a new joint-stock company (Aktiengesellschaften and Kommanditgesellschaften auf Aktien) could be founded; for shares issued at higher than nominal value, 50 percent payment was required. ${ }^{3}$ Underwriting issues on the basis of subscriptions, for either new or transformed firms, could therefore cause long delays and possibly failure of an issue to meet regulations and deadlines. Having an informed intermediary take over the full capital to be floated provided insurance to the company that the issue would succeed. In the German financial system, the logical providers of simultaneous underwriting services were the universal banks and, for large issues, the Berlin-based great banks in particular. Thus, while the central aim of the law was to provide insurance for potential investors, the regulation may have also affected the development of the universal banking sector.

Indeed, Robert Liefmann (1921) attributed the institutional structure of the German universal banks to this practice of simultaneous company promotions, and Whale (1930) suggested that the 1884 company law solidified the position of the universal banks as industrial firms' main conduit to the securities markets. In particular, the need to pay up, and, in some cases, hold shares in advance of operations and trading required substantial resources on the part of underwriters and therefore encouraged universal banks to expand both their capital and their customer networks. These incentives grew in line with the volume of new share issues-whether resulting from flotations of new companies, conversions of old private firms into share companies, or mergers and acquisitions of existing firms. Although the universal banks, and the private banks before them, arranged most company flotations even before the 1884 law, Whale (1930, p. 43) noted that the new law "can be held to have influenced the situation, in the sense that it provided new reasons for the intervention of the banks at a time when the original reasons were losing some of their force." This conclusion may overstate the impact of the 1884 law: if the need for simultaneous foundings, and therefore for large, universal banks, stemmed from stipulations on paying up shares, then the 1870 law 
should have provided the necessary impetus long before the 1880's. Thus, Table 1 includes an "up" arrow for the impact on banking growth and concentration, but the effect should not be expected to be large.

In 1892, in response to major securities and commodities price declines in the previous two years, the legislature formed a stock exchange enquiry commission (Börsenenquetekommission) to investigate charges and recommend remedies. ${ }^{4}$ The law that resulted, the 1896 Börsengesetz, contained a number of provisions regarding the issuing and listing of securities. The arrows in Table 1 reflect the countervailing influences of this law. For joint-stock firms transformed out of existing private companies, the new law stipulated a waiting period of one year after entry into the commercial registry, as well as a published balance sheet and profit and loss statement for that year, before the shares could be admitted to official trading. ${ }^{5}$ In addition, only fully paid up issues could be officially traded. It is commonly believed that these restrictions, while perhaps protecting shareholders, created a need for greater bank credit, pushed more securities trading from the exchanges to the universal banks, and compounded the incentives for growth and concentration of universal banking stimulated by the earlier company laws.

The 1896 law also created new governing institutions for the exchanges to ensure closer scrutiny of new issues and stipulated tighter enforcement of regulations and legal recourse to injured parties. Moreover, the law provided for greater independence in the body admitting securities to the exchanges (the Zulassungstelle); dictating, for example, that half the members must not be listed in the stock exchange register, a third must not be involved in securities trading, and nobody involved in a new issue would be permitted any say in the acceptance of that issue to trading. ${ }^{6}$ The legislation reinforced the liability clauses of the 1884 law, making underwriters specifically responsible for damages to investors stemming from false or misleading information provided in the required prospectus for new securities (unless investors could reasonably have known that the information was incorrect). Together, these stipulations were intended to assure investors of a minimum level of quality of securities traded at the exchanges and to ameliorate the natural information asymmetries between firms and outside investors as well as between underwriters and securities purchasers. If effective, the law should have improved confidence in the exchanges and promoted greater use of securities and of equities in particular. This effect corresponds to a "down" arrow in the third column of Table 1, since it means that business would be expected to increase at stock exchanges (and not necessarily at banks) and might even migrate from banks to markets. 
The influence of these protective provisions, however, may well have been offset by the restrictions on new issues and by the most contentious measure in the new law: the prohibition on futures trading in the securities of mining and factory enterprises as well as in a wide range of commodities (grain and mill products). The ban on futures essentially closed down the Berlin commodities exchange, and, it has been argued, hampered the operations of the spot securities market. The ban is also argued to have pushed more securities trading into the universal banking system, as those institutions attempted to simulate futures contracts. Naturally, centralized banks with larger clienteles and dealings in wider ranges of securities-in this case, the great banks-would have gained an advantage over smaller, provincial banks and private bankers. The lack of futures trading is also thought to have increased the demand for cash, and therefore for bank credit, for securities transactions. Thus, the futures prohibition is also thought to have spurred further universal banking concentration. Table 1 therefore indicates a positive effect of the futures ban on all three areas of influence. It is thought that these effects on concentration proved difficult to reverse and lingered even after the 1908 novelle rescinded the blanket prohibition of futures trading. So, while Table 1 indicates a negative effect for the lifting of the ban, such an impact is hypothesized to be small.

\subsection{Taxation of bourse transactions}

It is easy to see how imposition of taxes on securities market business might dampen market activity, particularly when substitute services are available. Stock exchange taxes, consisting of a stamp tax on final certificates of transfer (Schlussnotenstempel) and a tax on all new issues of securities (Emissionsstempel), were introduced in $1881 .^{7}$ In 1885 , a one-tenth per-thousand tax replaced the flat tax on trades. Nine years later, the tax was doubled to two-tenths per thousand and was imposed on all amounts-not just on every thousand marks. Very small transactions, those less than 600 marks, remained exempt. The 1900 stamp tax law eliminated this exception, increased all rates further, and initiated a tax on the issue and transfer of mining stocks (Kuxe). These changes represented major cost increases for the securities underwriting and brokerage businesses in the space of 20 years.

At the time of the 1885 tax legislation, some policy makers, economists and businessmen recognized that the tax might create an incentive for concentration in banking. Since banks could balance purchase and sale orders outside of the bourse and pay the tax only on the net transaction, large universal 
banks benefitted from a network externality of sorts: larger clienteles meant a broader market for securities and therefore more untaxed commissions on internal trades. Thus, the tax spurred universal banks to increase their customer base, and such growth meant encroachment of the large urban banks on provincial bank territory. The tax savings allowed larger universal banks to decrease commission rates to rates well below those charged by smaller, provincial banks. As tax rates increased, so did the savings from internal trading. This situation persisted until June of 1900, when the new tax law eliminated the exemption on internal, or compensatory, transactions.

Riesser argued that compensatory transactions gave the great banks an insuperable advantage over the provincial banks. The advantage of the large, Berlin banks was exaggerated due to the double taxation of provincial banks executing orders through their Berlin correspondents. ${ }^{8}$ Until this system was amended by the 1894 stamp act, the extra tax burden added to the commission and brokerage costs borne by the provincial bankers, and therefore by their customers. Table 1 indicates the contradictory influences that the 1900 tax law had on the concentration and business of the universal banking sector: a positive impact from tax rate hikes but a dampening effect from the closing of loopholes favoring large banks.

\subsection{Price setting on the exchanges}

German exchanges were call markets throughout the period studied here, and price setting changed comparatively little during that time; though the 1884 and 1896 stock exchange laws formalized certain institutions that were already common practice, at least in Berlin. Official brokers (vereidigte Maklern) set securities prices based on the unified price system, in which brokers balanced purchase and sale orders and determined, after a round of price announcements and recalculations, the final binding price for all orders placed that day. According to the 1884 law, the official brokers were appointed for life terms and were legally prohibited from trading on their own accounts or joining with other brokers.

The unified price system arguably insured a significant level of transparency and therefore confidence in securities transactions on the Berlin exchange. ${ }^{9}$ On the other hand, contemporary observers claimed that price setting was not exact or reliable enough and that, in setting the market price, the brokers often followed the wishes of interested bankers, especially when a deal could not be executed on the given day. ${ }^{10}$ Such critics added to the voices calling for reform in the early 1890 's. 
Thus, it is difficult to hypothesize about the impact of the 1896 law on confidence in and use of the exchanges. To the extent that pricing institutions predated the 1896 law, little change would be expected. But the new regulations also stipulated that prices be officially set by the exchange directors, in the absence of outsiders (i.e., only the commissioner, secretary, brokers, directors, and representatives of other trades prescribed by exchange regulations were permitted to be present). If these rules minimized opportunities for tampering with independent price setting, then the law may have indeed improved transparency and public confidence in the exchanges. Thus, for the price-setting components of the 1896 law, Table 1 indicates a negative hypothesized influence on the business turnover of banks relative to markets.

\section{Empirical analysis of regulatory and tax influences on universal banking, 1884-1913}

The preceding discussion presents three separate ways in which regulations enacted between 1884 and 1913 influenced the universal banking sector-growth of the sector overall, concentration in the sector, and the expansion of the sector's business at the expense of securities markets. The goal of the following analysis is to create quantitative measures of these three types of impact, recognize general patterns in these variables over time, and identify regulatory influences while controlling for other relevant factors.

The catalog of effects given in Table 1, however, demonstrates the difficulty of isolating the influence of individual pieces of legislation. Between 1884 and 1900 seven separate legislative or economic events have a positive hypothesized impact on universal banking concentration, and six have a positive hypothesized effect on overall growth of the universal banking sector. No events before 1900 have negative hypothesized effects on either growth or concentration, but such effects appear in both 1900 (for concentration) and 1908 (for growth overall). Effects of regulatory changes can also be difficult to pin down, because legislation is anticipated or is enforced gradually. The 1896 stock exchange law is widely claimed to have made a significant impression on universal banking growth and concentration. Yet the enquiry commission's deliberations began in 1892, and most of the law's provisions were not implemented until January 1, 1897. Most banks were likely aware of the impending need for greater capital well before the implementation of the law. Even in the case of tax increases, effects may be seen over the course of 
more than one year, particularly when the legislation appears mid-year (as in the three major tax laws of 1885, 1894, and 1900). As a result, even disregarding non-regulatory forces, we might find a general trend toward growth and concentration in the universal banking industry, rather than large, discreet shifts in the two variables.

For the third category, the use of universal banks relative to securities exchanges, the influences are split: three positive hypothesized effects and three negative from 1884 to 1908 . In two separate cases-the 1896 stock exchange law and the 1900 stamp act-the same piece of legislation contains clauses with countervailing hypothesized influences. At the same time, however, all three of the effects that might plausibly retard a shift of business from markets into universal banks are thought to have been minor compared to the forces pushing in the opposite direction. Thus, here too we ought to expect a positive trend over the period. But since there is wider spacing in the events thought to influence the relative use of banks and markets, discrete changes may appear more prominently. At the same time, one should keep in mind that tax increases may even result in higher measured turnover, because prices may rise even though quantities fall. For the 1896 law, since effects on the business of the exchanges would likely have been delayed until the provisions were in force, we should expect a significant change immediately following implementation, or, given the annual frequency of the data, by the end of 1897 . It should be noted, however, that the law left some uncertainty about what exact business was prohibited, and some have claimed that enforcement by the courts varied. ${ }^{11}$ Thus, even for restricted securities, some futures trading probably persisted after 1897, and this delay might have spread the effects over a number of years.

Unfortunately, since most of the necessary data series begin in 1884, it is impossible to provide a baseline against which post-1884 data can be compared. Given the imposition of the percentage tax on stock transfers in 1885 , it would be difficult to disentangle the influences of the new company law and the increased taxes in any case. The following analyses therefore restrict attention to legislative and economic events after 1884. The remaining data series still permit investigation of the regulatory changes of the 1890s. Even if the 1884 law set the processes of growth and concentration into motion, the later laws are commonly viewed as even more influential on the German economy. If these laws were as significant as hypothesized in past historical work, their effects should compound existing trends and therefore be picked up in the current analysis. From an historical point of view, this marginal impact is of the greatest interest. 


\subsection{Universal Banking Concentration}

The first hypothesis is that the universal banking industry became significantly more concentrated between 1884 and 1913, and that this tendency was most pronounced after the tax and regulatory changes of 1894 and 1896. Since nearly the beginning of the universal banking system in Germany commentators have remarked, sometimes with great alarm, on the concentration of economic power within the great banks. ${ }^{12}$ In 1910, the well-known great banker Jacob Riesser proclaimed that “...the movement toward concentration precipitates itself headlong like a flood and proceeds with awful violence, as if all contrivances for stemming the tide had been swept away and all dams had been destroyed by some natural catastrophe."13 Despite the drama and apparent certitude of the claim, it remains unclear how much concentration increased in Germany, what caused the increase, and how the changes compare with other countries in the same period.

Concentration may be measured several ways, and different measures offer varying views of the universal banking industry over the $1884-1913$ period. In the following, I construct five-firm ratios using two different balance sheet indicators (total assets and total share capital) and two different denominators (all joint-stock credit banks and the sum of such banks and private banks). The joint-stock credit banks are those termed Kreditbanken in the Deutsche Bundesbank (1976) series. Since private banks reported no consistent balance sheets, they are only included for total assets and then only included at estimated values. As a supplementary measure, using the Deutsche Bundesbank's 'Berlin great banks' series, I also include the ratio of assets to total universal banking assets (including and excluding estimates of private bank assets). These figures overstate the growth of universal banking concentration in Germany, since the Deutsche Bundesbank series for great banks includes 7 banks from 1883-1893, 8 banks from 1894 to 1897, and 9 banks from 1898 to 1914. On the other hand, the change in the number of banks considered Berlin great banks reflects the movement of two important provincial banks into Berlin. Therefore, the measure offers insight into the predominance of Berlin within the whole of the universal banking sector. While a Herfindahl-Hirschmann index might show somewhat different patterns of concentration, the results would likely be qualitatively similar to the ratios used here. Given the absence of data on private banks, particularly on all banks individually, it would be virtually impossible to calculate the $\mathrm{HH}$ index accurately. 
All of the concentration ratios take a given set of institutions and single out the largest $\mathrm{N}$ firms among them. As with any industry, such calculations mask concentration created by inter-firm cooperation or partial absorption of some firms by others. In the current case, such engagements emerged in the form of groups of provincial banks acting in concert with various Berlin great banks. The great banks formalized relationships with their group banks through supervisory board representation and sometimes also through share purchases. Some such links were two sided, but provincial banks often lost some independence in the deal. ${ }^{14}$ In addition, between 1905 and 1909, the Schaaffhausen'scher Bankverein and the Dresdner Bank-two of the largest great banks—-formalized their close working relationship in a community of interest (Interessengemeinschaft).

In order to measure concentration, of course, a line must be drawn. The extent of integration of the provincial banks varied significantly, and all group banks remained at least partially independent unless and until they were fully absorbed by another bank. Integration of bank groups could progress slowly and is also difficult to measure with existing data. The Schaaffhausen-Dresdner IG is a good example of the impermanence of some cooperative arrangements as well as the fact that not all led to merger. Ultimately, Schaaffhausen was taken over by Discontogesellschaft, and not by its previous partner, Dresdner. Given these considerations, bank group members that are legally separate entities and are reported among the provincial banks in the Deutsche Bundesbank statistics are included in the denominator for the current measures of concentration.

Concentration ratios measured in this manner indicate little growth in the share of the largest banks in any of the variables used. Figure 1 plots five-firm ratios for total assets and share capital as well as great-bank ratios for total assets and deposits for 1884-1913, and Table 5 reports estimated five- and tenfirm ratios for total assets for 1890, 1900, and 1910. The previous section hypothesized concentration increases after 1885, 1893, 1894, 1896, 1897, and possibly 1900 as well as a general trend toward concentration over the period. According to this first measure, the prediction appears confirmed only for 1893-94. The asset-based ratio increased five percentage points (to 39.6) between December 1892 and December 1894 and climbed just over 43 percent over the course of 1895 . Though this development at first would seem to correspond to the legislative changes of 1892-96, a causal interpretation is undermined by the steady decline in the ratio between 1896 and 1901 (back down to 37 percent) and the flatness of the 
ratio in the mid-1880s. Putting these findings together, and still ignoring the private banks, the lack of a steady trend toward concentration over the period is clear. The top five banks began the period with 37 percent of joint-stock bank assets and ended it with just short of 42 percent. The ratio declined on net in the latter half of the 1880s and remained around 33 to 34 percent in the early 1890 s.

Ratios using share capital provide even less support for the hypotheses. Though the five-firm capital ratio increased from 34 to 39 percent over the course of 1895 , the ratio had generally declined up through 1894 and continued to drop steadily between 1895 and 1901 (to a low of just over 31 percent) and then between 1904 and 1912 (from 37 to under 31 percent). The difference in results sheds some light on the relative use of capital in the expansion of joint-stock universal banks. The fact that asset concentration ratios grew relative to share capital-based ratios suggests that the largest banks increased their assets more through deposits than through share capital, compared with the provincial banks. In other words, since a given volume of deposits very likely corresponds to a larger number of individual investors than an equal amount of share capital, the great banks appear to have been expanding their customer base rapidly at the expense of provincial universal banks.

These findings also corroborate the claims of Weber (1915), regarding the concentration of German deposits within the Berlin joint-stock banks. The point raises a subsidiary but closely related issue: the ability of the largest banks to foster their brokerage and investment banking business through the development of deposit networks throughout the country. By increasing their presence outside Berlin, the great banks not only expanded their funds for lending, but they also created demand for securities, both new and old. Thus, since the hypothesized incentives for banking concentration stem from provisions regarding the securities business, we should expect that the greatest increases in concentration appear in measures based on deposits.

The great-bank ratios show similar patterns. While the great banks' share of total assets rose from around 43 percent in the early 1890's to over 55 percent in 1905, the ratio changed much less over the full period-from approximately 48 percent in 1884 to 52 percent in 1913-and experienced far greater growth during and after World War I. Corresponding ratios for share capital show even less change-beginning and ending the period at about 40 percent. Deposit-based concentration ratios for the great banks (not pictured) follow nearly the same path, though the ratio is slightly lower in the years before 1900 and 
slightly higher thereafter. As hypothesized, the deposit-based ratio increases the most, but the total change is still rather small (growing from 47 percent in 1884 to 53 percent in 1913). Even more pronounced than with the 5-firm ratios, concentration increased the most in 1888, 1894-95 and 1901-4, did not increase much at all in the wake of the 1892 formation of the stock exchange inquiry commission, and actually declined following the 1897 implementation of the 1896 law. ${ }^{15}$

So far, these measures exclude an important component of the German industrial banking system: the private bankers. The commercial and investment banking industry underwent significant organizational change over the course of the nineteenth and early twentieth centuries, with private bankers comprising a declining share of the sector, especially toward the end of the period. Private bank assets, by their nature, are difficult to count, but Goldsmith's (1969) estimates suggest that they amounted to at least that of jointstock banks in the 1880 's but only half between 1900 and 1913 . When private banks are included, the concentration ratio for total assets falls to 16 percent in 1884 but reaches over 33 percent by 1913 . Advanced statistics are unnecessary to spot the positive trend here, and this trend also swamps some of the yearly changes that are apparent in the joint-stock only ratios. Most notably, the inclusion of private bank assets smooths the decline and then rebound of the joint-stock ratios between 1895 and 1905, giving the appearance of steady increase. Interestingly, the sharp increase of 1892-5 and the decline of 1906-08 are both still apparent in these new ratios.

One should consider, however, whether private banks ought to be included in full in the denominator of these concentration ratios. Only a small percentage-albeit mainly the largest-of these banks competed with the joint-stock universal banks in commercial banking, brokerage, deposit-taking, or underwriting. Many served a clientele that never dealt with joint-stock universal banks. The relevant measure of universal banking concentration may therefore lie somewhere between those computed only with joint-stock banks and those that include all private banks. Unfortunately, there would be no way to determine the assets or even the existence of each and every private bank, much less categorize them all according to their clientele and lines of business.

The figures calculated here differ slightly from those presented in Tilly (1995), in which Figure 1 shows the equity capital of the six largest Berlin banks accounting for under 13 percent of the total in 1883 and just under 40 percent by 1913 (and peaking at 44 percent in 1905). The data in the present paper 
come from Deutsche Bundesbank (1976), Saling's Börsen-Jahrbuch, and Handbuch der deutschen Aktiengesellschaften for the joint-stock banks and from Raymond W. Goldsmith (1969), for the private banks (using linear interpolation between his estimates for 1880, 1900, and 1913). Tilly uses figures from Bosenick (1912) and the Deutschen Ökonomist for the Berlin banks. The source of the discrepancy is unclear, but it may be the calculation of private bank assets. Since private banks were not compelled to report any financial information, particularly not on an annual basis, it is exceedingly difficult to determine the size of the sector. ${ }^{16}$ If the Tilly figures use total assets of private banks but only equity capital for the joint-stock banks, then the concentration ratio would appear to be lower throughout the period, but this difference should be offset by the fact that he uses six banks rather than the five used here. While the differences in individual years are rather small, they yield obviously disparate trends in concentration overall.

Concentration in universal banking certainly increased at least somewhat over the period in question; but the change, even considering the private bankers, was likely more moderate than that perceived by contemporaries or by historians who have not closely examined the relevant data. The question remains, however, whether the observed increases in universal banking concentration resulted from specific regulations, from changes in the economy (such as growing concentration in industry), or from some combination of these two factors.

Rather than simply comparing concentration before and after an event, it is therefore preferable to model the concentration ratio as a function of explanatory variables, some of which are related to regulatory changes. Regulatory changes are typically qualitative and are therefore represented by the timing of their enactment. The one exception is taxes-a variable that may be measured simply by its percentage rate. In the analysis to follow, I model universal banking concentration as a function of such time and tax rate variables along with other variables representing influences on concentration. Analysing the impact of regulations presents difficult problems. As noted at the outset of this section, the difficulty of identifying unique causes for the observed changes in the current case is particularly severe, especially in the period from 1892-1900. The few studies that have attempted a quantitative assessment of legal changes have focused exclusively on the 1896 stock exchange law, including an indicator variable only for the post-1896 period (Tilly, 1995). Other events in the mid-1890s also encouraged capital increases and 
greater bank concentration: especially the 1893 formation of the Rhenish-Westphalian Coal Syndicate and the 1894 doubling of the stock transfer tax (and other tax increases). Thus, in addition to a post-1896 indicator, I include variables for post-1892 and post-1894 sub-periods along with a trend variable. The post-1892 variable represents the formation of the commission, while the 1894 variable represents the doubling of the stock transfer tax. These indicator variables may yield significant coefficients simply because future changes are large enough to influence the average over the whole sub-period. To help determine whether there was any upward shift in the trend after a certain point, I therefore also interact the sub-period indicator variable with the trend.

Riesser claimed that “...concentration in banking, which had been greatly influenced both in the extent and rapidity of its progress by developments in industry, and particularly by the formation of cartels, in turn helped to bring about concentration in industry." ${ }^{17}$ Given the lack of necessary data, economy-wide changes in industrial organization are not directly accounted for in the regression. Nonetheless, some reasonable variables are available to proxy for economic influences, such as availability of economies of scale and scope, that may lead larger banks to increase market shares at the expense of smaller banks. Partially in line with Tilly (1995), I include real NNP, total volume of new domestic share issues (in 1913 marks), average face value of new domestic shares (in 1913 marks), and an index of stock prices.

Volume of share issues represents demand for underwriting and placement services. Increases in share volume should correlate positively with concentration, since larger banks located near securities markets are able to produce these services more readily than smaller banks located in the provinces. The average face value of new shares provides a measure of the scale of individual issues. Even more than the overall volume of issues, this variable captures the need for large intermediaries that could take share issues to market. Real net national product and the annual stock price index control for other economic influences on universal banking concentration. Given their stronger orientation toward the securities business, especially in Berlin, the largest universal banks benefitted disproportionately from upswings in the stock market. Thus, universal banking concentration should increase during bull markets. Concentration is measured by the five-firm ratio for total assets, including private banks. Because of the potential smoothing problem stemming from the interpolation of private bank assets, Table 2 also reports regression results for the five-firm ratio based only on joint-stock bank assets. 
The analysis yields several key points. ${ }^{18}$ First, while there is a significant trend toward concentration over the full period from 1884 to 1913 when we consider estimated private banking assets, concentration measures constructed on the basis of joint-stock universal banks yield a much smaller trend (coefficient estimates are actually negative, though insignificant, once other variables are introduced). In particular, the estimated trend coefficient is 0.03 when private banks are included but is 0.01 when they are excluded. These statistical results simply bear out the situation that is rather obvious from Figure 1, but serves as a reminder that one's understanding of banking concentration depends on one's views about the relevance of private banks in the concentration measure.

The regression results also reveal something less obvious: that there was no marked increase in concentration-as measured by the share of the great banks in total universal bank assets-after 1892, 1894, or 1896 (Table 2). The interaction of these sub-period indicators with the trend variable produces similarly insignificant coefficient estimates for this concentration measure. The joint-stock five-firm concentration measure, however, is significantly higher and increased faster after 1894 than before. Neither effect emerges for the post-1892 or post-1896 indicators. These findings would suggest that the tax increase of 1894 was the most significant of the regulations imposed during this period, and that indeed the muchdiscussed stock exchange law of 1896 created no apparent effect. Such an inference is further bolstered by the significance of the turnover tax variable for the first concentration variable (including private banks). Moreover, in this specification (column four of Table 1), the tax variable renders the trend insignificant. Somewhat puzzling, however, the tax variable is statistically insignificant for the joint-stock-only concentration measure.

The lack of response to the formation of the 1892 stock exchange enquiry commission may indicate that bankers only gradually determined the ramifications of the impending legislation, expected the law to be weak, or calculated that the provisions did not warrant early reaction. Indeed, Borchardt's $(1999,2000)$ discussion of Weber's work on the enquiry commission suggests that the promulgation of a stock exchange law by 1896 took many observers by surprise. It is also possible that the universal banks saw the merit of increasing their capital in 1892 but were unable to do so until the improvement of economic conditions beginning in 1894-at which point there were other reasons to expand. 
Economic variables do provide further explanatory power. The size of new equity offerings, measured by the average face value of new domestic share issues (in real terms), obtains significant, positive coefficient estimates, particularly for the measure including private banks. In addition, the stock index is moderately significant in some models. ${ }^{19}$ Both measures may capture the effects of growing industrial cartelization and concentration as well. Average face value of new stock issues, likely the closer proxy for industrial concentration, is the statistically stronger of the two measures. To the extent that industrial change proceeded consistently over time, the annual trend variable probably also subsumes such effects. Total volume of new issues and real NNP are both statistically insignificant, suggesting that the overall growth of industry is not closely linked to banking concentration. It may prove fruitful in future work to analyse the relationship between direct measures of industrial concentration and concentration in the universal banking industry.

These results differ from those in Tilly (1995) and Wetzel (1996). Tilly, for example, regresses his measure of universal bank concentration on real NNP, real volume of new issues (total value in real marks), and a post-1896 indicator variable. Tilly finds that NNP and the post-1896 dummy variable are positive and statistically significant but that volume of new issues is insignificant. There are problems, however, with these models. The use of the post-1896 indicator variable without a year variable ignores other regulatory influences at work (such as tax laws) and also fails to account for the potential overall trend toward universal banking concentration. In addition, OLS regression fails to correct for the obvious serial correlation in the errors. In the present analysis, Cochrane-Orcutt regression greatly reduces the coefficient (and its significance) on the post-1896 indicator variable. These methodological differences are important, and they make the current findings more powerful than previous ones.

Part of the discrepancy between the current results and those reported by Tilly, however, must stem from differences in the underlying data: using Tilly's specification on my data still yields insignificant coefficients on either a post-1896 or a post-1892 indicator. As my data come from the banks' annual reports (as reported in the HDAG and Saling's), there is good reason to trust the accuracy of the numerator of my concentration ratios. Moreover, the Deutsche Bundesbank statistics provide the most widelyaccepted figures for total joint-stock credit (universal) bank assets, making the denominator of the jointstock-only ratio also highly dependable. As noted, private bank assets are difficult to estimate, and 
therefore any concentration ratio that attempts to account for private bank assets will lack precision. Thus, for conceptual as well as practical reasons, the joint-stock-only ratio reported here is likely the most accurate and compelling measure available. Such a ratio is not comparable to Tilly's more general ratio.

\subsection{Growth of universal banking}

Although expansion was likely most pronounced among the largest universal banks, regulatory change may have spurred a more general growth in the universal banking industry. Following a similar methodology as the concentration analysis, we can view overall growth of universal banking as a function of regulatory and economic variables: real NNP, total face value of new domestic shares in Berlin (millions of 1913 marks), average face value of new domestic shares in Berlin (millions of 1913 marks), an annual stock exchange index, sub-period indicator variables (for regulatory events), the turnover tax rate, and a trend variable. Average face value of shares and stock price levels are expected to be only weak correlates of growth, as they pertain disproportionately to the largest banks and their demand for working capital for securities transactions.

Because of the smoothing of the estimated private bank assets, this analysis focuses on the jointstock banks. The dependent variable is the real value of total joint-stock universal bank assets, but average values of these banks' assets produce nearly the same results. The inclusion of private banks has little impact on the conclusions of the analysis, since it is clear that estimated private bank assets increased little throughout the period from 1884 to 1913. Regressing the log of assets, in real terms, on a constant and time trend yields annual average growth rate estimates of less than half of one percent per year for the private banks, compared with a rate of 6.8 percent for the joint-stock universal banks. The growth in jointstock universal banking average stemmed both from the setup of new banks and from increases in the size of banks. Average assets per joint-stock universal bank grew at an estimated average of 3.6 percent per annum in this period. Given the historical record describing the absorptions of private bankers by jointstock banks, it is likely that the number of private banks was declining, at least in the decade before WWI. Thus, the fact that estimated private bank assets grew at all in real terms suggests that the remaining private bankers were actually growing as well. Not surprisingly, given the previous discussion, great bank 
and provincial bank assets demonstrate similarly strong trends. ${ }^{20}$ This result further demonstrates the extent to which the trend on concentration (measured with private bank assets) stems from the relative lack of growth of private bank assets.

Table 1 points to $1892,1894,1896$, and 1900 as hypothesized inception points for growth spurts for the universal banking sector. As with concentration, however, the results reported in Table 3 show that none of these indicator variables yields statistically significant coefficients either in their levels (that is, a shift in the constant) or when interacted with the trend variable. This insignificance could imply that the legal changes of the late nineteenth century made no perceptible impact on the growth of the universal banking sector. The stock exchange tax variable (last column of Table 3), however, suggests a slightly more complex story. ${ }^{21}$ The turnover tax rate relates very positively to universal banking assets, even though the post-1894 sub-period variable does not. Interestingly, however, the significance of the tax variable in the regression hinges on controlling for the real volume of new issues. The volume of new issues grew rapidly over the period but was slightly, though not statistically significantly, dampened by the imposition of stock taxes. Only after controlling for this underlying force for expansion, and its negative relationship to tax rates, does the growth effect of the tax rate increases emerge.

In line with expectations, particularly in light of the immediately preceding discussion, the volume of new issues of domestic shares relates significantly (positively) to joint-stock universal bank assets. After the overall trend, the new issues effect is the strongest, both in magnitude and statistical significance. Since the regression also includes a trend variable, of course, we ensure that the effect is not simply proxying for a trend variable. This result, along with the turnover tax finding, underscores the importance of the securities business to the universal banking sector and, more broadly, the inter-dependence between universal banking and securities market institutions. Various authors (Riesser, 1910 and Weber, 1915, for example) estimate great bank commissions on trading and underwriting of securities at approximately 30 percent of profits in the early twentieth century. Provincial banks, as a whole, depended less on the securities business, and this fact is born out in re-running the growth regressions using only provincial bank assets. If we consider only provincial banks, both the new issues variable and the tax rate lose their magnitude and significance. 
General economic prosperity also appears to explain a greater part of the observed trend in universal banking growth than do regulatory events. In contrast to concentration of assets, logged levels of real universal bank assets relate positively to changes in real net national product. So, it appears that growth in the real economy goes hand in hand with development in the financial sector-at least those financial institutions most responsible for financing industry. It is worth noting, however, that provincial bank assets are unrelated to real NNP, so that the real-financial link is not as strong as might be expected. This finding is relevant to the recent literature on the finance-growth relationship, and tends to qualify some of the claims of the causal importance of financial institutions for real growth. Specifically, if financial growth were a primary impetus for real development, then surely the provincial universal banking sector, not just the great banks, should contribute significantly to real growth. ${ }^{22}$

Two final variables that related positively with universal banking concentration, average value of new issues and share price levels, do not help explain growth in the universal banking sector overall and are therefore excluded from the reported regressions. Both of these variables were expected to be weaker correlates, and this expectation is borne out by the results. The other findings are robust to these specification changes.

\subsection{Universal banks versus stock markets}

While it is now clear that German universal banks, and especially the largest such institutions, expanded operations over the period 1884-1913, the question remains whether banks simultaneously usurped business from the exchanges and, if so, whether regulatory change encouraged this displacement. The relevant line of business, of course, is securities trading, since bankers could partially substitute for the exchanges in these transactions. Unlike concentration or size, quantity of business done is very difficult to measure, particularly for securities trading. It is nearly impossible to quantify trading volumes outside official secondary markets in Germany, and the universal banks themselves did not report the volume of such business. The business turnover of universal banks may serve as a useful, though obviously imperfect, proxy for securities trading within the universal banking system. The variable at least reflects the growing business of the universal banks, a significant portion of which was devoted to brokerage 
transactions, and may be compared with the volume of turnover on the exchange. ${ }^{23}$ In addition, using this variable allows comparison with Tilly's (1995) results, since he uses a similar measure.

There is little theoretical work on the determinants of trading volume; and at least one prominent theory implies that there should be no trading at all: prices provide 100 percent of portfolio adjustment. ${ }^{24}$ Thus, in the absence of a standard, empirically-testable model of stock exchange volume, the following econometric models (Table 4) should be interpreted as revealing correlates rather than structural interpretations. Annual stock exchange turnover fluctuated significantly throughout the period, but regression estimates show a significant negative trend in real turnover over the period. Much of this negative trend results from the extreme upswing in 1888-90 and the similarly dramatic drop in 1907-08.

Following the previous two analyses, I estimate relative turnover as a function of economic and financial variables (real NNP per capita and an annual stock exchange index), sub-period indicators representing regulatory changes, tax rates, and a trend variable (Table 4). Reflecting the growth pattern found for the previous two variables, universal bank turnover did rise relative to market turnover over the course of the late nineteenth and early twentieth centuries. A regression of the logged ratio on a trend variable from 1884 to 1913 produces estimated annual average increases of ten percent. While the trend toward greater relative universal bank business over the period is clear, there is also noticeable fluctuation throughout the period. No significant increases emerge for 1892, 1896, or 1900, either in overall levels or break in trend. Yet the post-1894 variable is significant on its own and when interacted with trend-suggesting once again that tax measures were the primary area in which regulatory change made a palpable impact.

Continuous variables for actual tax rates or percentage changes in those rates, however, provide negative explanatory power for the increase of universal banking business relative to the exchanges. Relative turnover is clearly positively correlated with both tax rates, and simple OLS regression yields very significant positive coefficients of taxes. Yet there is a great deal of autocorrelation in the series, and Durbin-Watson statistics are extremely low. Once trend is accounted for, the additional effect of the taxes (in levels or differences) is negative. The causal link, however, may run in the opposite direction. Cochrane-Orcutt Regressions that replace the turnover ratio with the numerator and denominator of that ratio, and control for the same influences controlled for in the ratio regressions, indicate that the tax effect 
comes from a very significant positive relationship between issue tax rates and stock exchange turnover. One might reasonably speculate from this result that bursts of activity on the stock exchange allowed tax increases to be implemented. But since volume is composed of price and quantity, it is still technically possible that increasing the tax on issuing securities increased the measured volume of trading on exchanges through a price effect.

Despite the significance of the post-1894 indicator, the only discontinuous increases in the ratio appear after 1907, when there were no regulatory measures introduced that could be expected to have produced such an effect. Joint-stock universal bank turnover began 1907 at 84 percent of Berlin stock exchange turnover, but ended the year at over 171 percent of the market's turnover. The ratio then increased over 20 percent in 1908, but returned to its pre-1907 course in 1909. By 1910, universal bank turnover was back to 80 percent of market turnover, but it began another upswing to 149 percent in 1913 . As figure 3 illustrates, the majority of changes in the turnover ratio stem from large changes in the turnover of the exchange, and 1907 was a particularly troublesome year for the German stock markets. For the most part, universal banking turnover progressed in a rather steady manner after the beginning of the economic expansion starting in 1894.

Not surprisingly, given the presence of stock exchange turnover in the denominator of the turnover ratio, the stock price index offers strong, negative predictive power in the regression analysis. Since market turnover, or volume, is real price times quantity, the real price of securities must be a component of that variable. In the current study, however, the correlation between stock exchange turnover and securities prices is weakened, because trading volume is estimated from tax receipts, rather than from direct records of trading activity. Indeed, curiously, Berlin market turnover itself is hardly correlated with the stock price index (less than 8 percent for real volume and 28 percent for nominal volume). The much tighter correlation comes between universal bank turnover and the stock price index (70 percent). Thus, the turnover ratio is actually positively related to the stock price index in a simple correlation. The exclusion of the stock price index from the regressions has one effect: it eliminates the significance of the post-1894 variable (both alone and interacted with trend).

Real indicators of economic activity, represented here by real NNP per capita, are also insignificant in explaining relative bank turnover. Given the lack of theoretical modeling for bank or market turnover, 
this result is not unexpected. The fact that the regulatory variables provide little statistical power is at least in line with the findings for concentration and universal banking industry development. Thus, if the jointstock universal banks were gaining business at the expense of the exchanges, it is difficult to tie that development closely to the regulatory changes of the 1890's.

\subsection{Impact of regulation versus general trends}

The findings here suggest that, even though regulatory changes and tax levies on securities business in theory may spur universal banking concentration, growth of the corporate banking sector overall, or displacement of business from markets to banks, the new German laws of the 1890's made little observable impact. Such a finding may result from a number of circumstances. First, the laws may really have had little impact, either because the changes were small or because the provisions were not fully implemented. Second, the laws may have only added to other factors-such as new efforts to capture economies of scale and scope in financial services itself and responses to the growing scale of industrial firms financed by the universal banks-that were already encouraging changes in the industrial organization of universal banking. In other words, the laws may have actually had some discreet impact, but they may have been masked by the other changes in the economy of the time. Third, the laws may have had the expected impact, but the effects may have been spread over several years-giving the impression of a general trend.

It is difficult, of course, to differentiate among these three possible interpretations, but international comparison may help. Comparing Germany with countries that did not impose such stock market regulations and did not levy similar taxes at the same time offers insight into general trends in the banking sector over this period. From this perspective it appears that changes in the German universal banking industry did not hinge on the implementation of the 1896 stock exchange law or even on the levying of taxes throughout the 1884-1913 period. In the case of universal banking concentration, for example, it is commonly argued that several other European countries underwent similar adjustments to their banking industry structure over the same years, despite the wide variation in their regulatory systems. ${ }^{25}$

The English financial system (and that of the U.K. more broadly) makes a particularly useful comparison: it was unconstrained by regulations like the Germans', maintained a very active stock market, 
and had specialized commercial banks rather than universal banks. By the turn of the twentieth century, the government imposed no significant barriers to deposit banking growth and concentration, having eliminated size restrictions during the liberalization of banking laws in the 1820s.

Two points are clear from a comparison of concentration ratios (Table 4 and Figure 3). First, despite the apparent divergence in system design, the British commercial banking industry was just as concentrated as the German universal banking industry between 1884 and 1913. In 1890, estimated fiveand ten- firm ratios were very similar in the two countries-17 and 29 percent in Germany and 21 and 32 percent in the United Kingdom. By 1910, the top 5 and 10 commercial banks held 36 and 56 percent of assets, respectively, in the U.K. (43 and 65 in England and Wales only), but the top 5 and 10 universal banks in Germany held 31 and 44 percent of assets, respectively. ${ }^{26}$ Second, in both countries, the greatest surge in banking concentration came during and after World War I-long after Germany's regulatory changes in the late nineteenth century. By 1920, both countries had 5-firm ratios of over 60 percent, and England and Wales was still slightly ahead of Germany (65.5 versus 62 percent). For Germany, this change represents a tripling of the growth rate of concentration (including estimated private bank assets), from 2.9 to 8.7 percent per year on average, in the 1884-1912 versus 1913-1920 periods.

Evidence on the expansion of the two banking systems also suggests that Germany was not propelled toward extreme bank-orientation by the 1890s taxes and regulations. Indeed, viewing from the total size of the universal/deposit banking sectors relative to the size of the economy (measured as national product), it appears that the German banking industry merely began to catch up with the British over the course of the late nineteenth and early twentieth centuries. Even by the start of World War I, the point at which most scholars acknowledge that the German economy had successfully industrialized, the German universal banking sector (including estimated private bank assets) was still smaller than the UK deposit banking sector, relative to national product. ${ }^{27}$

The comparison with Britain, as well as the extension of the time series to 1920, suggests that forces other than regulation played the major part in the industrial organization of the German universal banking sector. Thus, even if it is impossible to prove conclusively that regulation had no impact, it is possible to surmise reasonably that universal banking concentration and growth would have progressed rapidly even without regulation. There are several possible explanations for such a trend toward growth 
and concentration: increasing demand for a few large banks to serve growing and merging industrial firms, increasing availability of scale and scope economies in the financial services business itself, or a simple progression toward a more rational structure in the banking sector (identifying and capturing existing economies of scale and scope or stability gains from branching). In fact, all three possibilities may have worked in concert. ${ }^{28}$ Clearly, in light of the different regulatory regimes in the two countries, nonregulatory explanations should be explored. In particular, the connection between industrial and banking concentration requires further investigation. In Britain, the existing evidence for a causal link is weak; but for Germany, the proposition has yet to be tested rigorously. ${ }^{29}$

Even if there is no direct connection between industrial and financial concentration in general, the possibility remains that banking is, or was becoming, a naturally oligopolistic business and was simply progressing towards a more ideal industry structure in many countries. Such an hypothesis underscores the possibility that concentration is unrelated to the form of banking institutions (universal versus specialized) and in itself may not erode, but rather enhance, consumer welfare. For example, all types of banking institutions may benefit from branching because of economies of scale in advertising and marketing, greater opportunity for matching supply and demand for capital, or increased diversification and stability. Concentration that comes with increased branching may therefore raise the efficiency and stability of surviving banks while placing more banks in competition with one another. Small banks with local monopolies may become branches of larger banks; and multiple national banks may open small deposit office in the same area. Such branching-based expansion was the pattern in Germany-and many other European countries-from the mid-1890s until well after World War II. ${ }^{30}$ Industry efficiency is notoriously difficult to assess empirically, but future research should consider the impact of increasing concentration on market power and efficiency in banking. ${ }^{31}$ It may well be that the historical literature has overemphasized the concentration movement in German banking, because of a presumption of anticompetitive behavior that did not materialize or is at least not directly related to that concentration. 


\section{Conclusions}

This paper investigates the impact of regulation and taxation on the German universal banking system between 1884 and 1913. The historical literature suggests that legal changes and tax levies produced marked increases in universal banking concentration, overall growth of the universal banking sector, and substitution of universal banking services for securities markets trading. The 1896 stock exchange law receives the greatest attention and is presumed to have made the strongest impression. The empirical exercises here examine all three types of development in the universal banking sector and produces several new insights.

The analysis reveals that assets, concentration, and relative turnover in the universal banking sector grew steadily from 1884 to 1913 . The appearance of continuously increasing concentration in the universal banking sector, however, hinges on the inclusion of estimated private banking assets in the concentration measure; and it is debatable whether most private banks should be placed in the same category as jointstock universal banks. None of the three variables demonstrate robust, discreet shifts after the enactment and implementation of any of the examined legislation. In particular, concentration among German universal banks grew at similar rates both before and after the 1896 stock market law, and there is little or no evidence that the 1896 legislation pushed business from the exchange to the universal banks in any significant way. The universal banking sector does appear to have grown faster after the general economic boom that started in 1894 , which likely contributes to the appearance of some increase in the three variables at that point. Moreover, rates of securities issue and turnover taxes appear in some models as significant factors in explaining concentration, growth, and relative turnover. Thus, if any of the legal changes made an impact, it appears to have been the increases in taxes. The tax effect, however, is not tremendously robust. Thus, the results imply that, at least after 1884, the tangible effects of individual pieces of legislation were small.

It is tempting to attribute the lack of discrete institutional change to early response to anticipated legislation or gradual enforcement of the enacted laws. Such a conclusion is undermined, however, by extension of the period of analysis to 1920 and by comparisons with a country that promulgated no such regulatory or tax changes (the UK). Transformations in the German universal banking sector accelerated 
during and after World War I, and concentration in particular progressed far more rapidly after 1912 than before. Moreover, despite the tax levies and trading regulations in Germany, the levels and increases in universal banking concentration were no greater than those experienced in the English commercial banking sector between 1884 and 1920.

These conclusions differ from those of other recent work on the German securities markets that focuses quite narrowly on the impact of the 1896 law. By acknowledging the many other factors at play during this period, the current work reveals the difficulty of isolating causal relationships between regulation and taxation on the one hand and financial system development on the other. Nonetheless, the findings still downplay the impact of the flurry of regulation and taxation in Germany in the 1884-1913 period, particularly in light of international trends in banking industry growth and structure that lasted until well after World War I.

\section{Acknowledgments:}

Thanks are due to participants at the First Conference on German Cliometrics held in Toronto, September, 1999, in particular Steve Broadberry, Scott Eddie, Albrecht Ritschl, Joachim Voth, and Simone Wegge. The author also thanks John Latting and an especially thorough anonymous referee for valuable comments on earlier drafts as well as the U.S. National Science Foundation and the American Academy in Berlin for financial support.

\section{References:}

Baker, M. and M. Collins (1990) "English Industrial Distress before 1914 and the Response of the Banks," European Review of Economic History, 3, 1-24.

Bosenick, A. (1915) Neudeutsche gemischte Bankwirtschaft. Berlin: J. Schweitzer Verlag.

Bund der Landwirte (1908) Das neue Börsengesetz. Berlin: Bund der Landwirte.

Buss, G. (1913) Die Berliner Börse von 1685-1913. Berlin.

Capie, F. and A. Webber (1985) A Monetary History of The United Kindom, 1870-1982. Volume 1. London: George Allen \& Unwin. 
Capie, F. and G. Rodrik-Bali (1982) “Concentration in British Banking, 1870-1920,” Business History. Deutsche Bundesbank (1976) Deutsches Geld- und Bankwesen in Zahlen, 1876-1975. Frankfurt am Main: Fritz Knapp.

Donaubauer, K. A. (1988) Privatbankiers und Bankenkonzentration in Deutschland von der Mitte des 19. Jahrhunderts bis 1932. Frankfurt am Main: Fritz Knapp Verlag.

Edwards, J. and S. Ogilvie (1996)“Universal Banks and German Industrialization: a Reappraisal.” Economic History Review, 49, 427-446.

Eistert, E. (1970), Die Beeinflussung des Wirtschaftswachstum in Deutschland von 1883-1913 durch das Banksystem. Berlin: Duncker \& Humblot.

Fohlin, C. (1999) “ Capital Mobilisation and Utilisation in Latecomer Economies: Germany and Italy Compared," European Review of Economic History, 2, 139-174.

Fohlin, C. (2000a) "Political, Economic, and Legal Factors in the Development of Financial Systems: International Patterns in Historical Perspective," Social Science Working Paper No. 1089, California Institute of Technology.

Fohlin, C. (2000b) "Banking Industry Structure, Competition, and Performance: Does Universality Matter?" Social Science Working Paper No. 1078, California Institute of Technology.

Fohlin, C. (2001) "The Balancing act of German Universal Banks and English Deposit Banks, 18801913," Business History 43, 1-24.

Gebhard, H. (1928) “Die Berliner Börse von den Anfängen bis zum Jahre 1896.” Dissertation: University of Erlangen.

Gerschenkron, A. (1962) Economic Backwardness in Historical Perspective. Cambridge, Mass: Belknap Press of Harvard University Press.

Gielen, G. (1994) Können Aktienkurse noch steigen? Langfristige Trendanalyse des deutschen Aktienmarktes. Weisbaden, Germany: Gabler Verlag.

Goldsmith, R. W. (1969) Financial Structure and Development. New Haven: Yale University Press.

Gömmel, R. (1992) “Entstehung und Entwicklung der Effektenbörse im 19. Jahrhundert bis 1914.” In Deutsche Börsengeschichte, edited by H. Pohl. Frankfurt.

Handbuch der deutschen Aktiengesellschaften, various years. 
Hoffmann, W. (1965) Das Wachstum der deutschen Wirtschaft seit der Mitte des 19. Jahrhunderts. Berlin: Springer-Verlag.

Lansburgh, A. (1909) Das deutsche Bankwesen. Berlin-Charlottenburg: Bank Verlag.

Liefmann, R. (1921) Beteiligungs- und Finanzierungsgesellschaften: eine Studie über den modernen Effekten-kapitalismus in Deutschland, den Vereinigten Staaten, der Schweiz, England, Frankreich und Belgien. Jena: G. Fischer.

Meier, J. C. (1993) Die Entstehung des Börsengesetzes vom 22. Juni 1896. Vol. 9. Studien zur Wirtschafts- und Sozialgeschichte. München: St . Katharinen.

Motschmann, G. (1915) Das Depositengeschäft der Berliner Großbanken. Leipzig: Verlag von Duncker und Humblot.

Riesser, J. (1910) Die deutschen Großbanken und ihre Konzentration. Jena: Verlag von Gustav Fischer. [English translation (1911): The German Great Banks and their Concentration. Published by The National Monetary Commission (Washington: Government Printing Office).

Schulz, W. (1994) Das deutsche Börsengesetz: Die Entstehungsgeschichte und wirtschaftlichen Auswirkungen des Börsengesetzes von 1896. Frankfurt: Peter Lang.

Schumacher, H. (1911) "Ursachen und Wirkungen der Konzentration im Deutschen Bankwesen," in Weltwirtschaftliche Studien. Leipzig: Veit.

Shepard, D. (1971) The Growth and Role of UK Financial Institutions, 1880-1962. London: Methuen \& Co. Ltd.

Tilly, R. (1995) “The Berlin Securities Exchange in National Context: Actors, Rules and Reforms to 1914.” Working paper, University of Münster, Germany.

Weber, A. (1915) Depositenbanken und Spekulationsbanken. Second edition, Leipzig: Duncker \& Humblot.

Wetzel, C. (1996) Die Auswirkungen des Reichsbörsengesetzes von 1896 auf die Effektenbörsen im Deutschen Reich, insbesondere auf die Berliner Fondsbörse. Münster, Germany: Lit Verlag.

Wiener, F. A. (1905) “Die Börse.” Dissertation: Berlin.

Whale, P. B. (1930) Joint-Stock Banking in Germany. London: MacMillan and Co. 


\section{Endnotes:}

1.See Hellmut Gebhard (1928), Rainer Gömmel (1992), Jacob Riesser (1910, 1911), Wolfgang Schulz (1994), Richard Tilly (1995), Christoph Wetzel (1996), and P. Barrett Whale (1930).

2.Of the various types of financial institutions in England (or in the UK more generally), the deposit banks are the closest in terms of functions and clientele to the German universal banks. The data sources vary in coverage, so that different variables are available for different geographic areas: England, England and Wales, or for the UK as a whole.

3.Text of share company law of 1884 (Gesetz, betreffend die Kommanditgesellschaft auf Aktien und die

Aktiengesellschaften), Articles 209e and 210. See Whale (1930), p. 331-333, for a discussion of different company forms in Germany.

4.On the impetus for the new law, see Fritz A. Wiener (1905), Georg Buss (1913), Johann Christian Meier (1993), and Schulz (1994).

5.Conversions (Umwandlungen) far outpaced new creations (Neugründungen) by the early years of the twentieth century and ran about equal in the end of the nineteenth century. (Adolf Weber (1915), pp. 224-5, and Whale (1930), pp. 41-2.) 6.Wiener (1905).

7.The stamp duty amounted to a flat 20 pfennig per trade (one mark for forward trades), while the issue tax required a 1 to 5 per-thousand fee on the face value of all new issues, depending on the type of security involved.

8.Riesser (1910, 1911), p. 619-0. See also Schumacher (1911), pp. 195-7, and Whale (1930), p. 34.

9.Schulz (1994) and Tilly (1995).

10.Wiener (1905).

11.Buss (1913), and Bund der Landwirte (1908).

12.See, for example, Alfred Lansburgh (1909). Riesser (1910, 1911), discusses some earlier German literature.

13.Riesser (1910, 1911), p. 614.

14.Whale (1930), pp. 30-1, lists the bank groups of the five largest Berlin banks. Only Deutsche (23) and Disconto (14 to 16) maintained large groups; Dresdner, Darmstädter, and Schaaffhausen (8, 3, and 3, respectively) had far smaller circles. By one estimate, the nine great banks included among their groups 39 percent (62 of 160) of all credit banks with capital over one million marks in 1913. In the same year, group banks controlled approximately 83 percent of working funds (the sum of share capital, reserves, deposits, and current account balances) of the 160 banks (Whale (1930), p. 32, citing data from the Deutsche f konomist, 1913.).

15.Only the 1894 increase can be partly attributed to the addition of one bank to the Berlin great bank category. There was no increase in concentration coinciding with the addition of a ninth bank in 1898, suggesting that the share of the alreadyincluded eight banks would have declined, as did the five-firm ratio. 
16.Alternative estimates have also been made for the number (as opposed to capital) of private banks, and such figures also vary quite a bit. For example, Pohl estimates 1300 bankers existed in 1871 and 1221 in 1913 (the latter from Deutsche Bundesbank (1976)). Klaus Donaubauer (1988), gives much higher numbers for intervening years: 2,000 to 2,500 between 1892 and 1902 .

17.Riesser (1910, 1911), p. 618.

18.The strong apparent serial correlation in the error is adjusted using a Cochrane-Orcutt regression. This procedure improves the Durbin-Watson statistics noticeably but also results in lower R-squared and F statistics. Hildreth-Lu and Prais-Winston corrections yield similar results. Further regression results are available from the author.

19.The stock index is highly correlated with both NNP and the volume of new domestic stock issues ( 80 and 87 percent, respectively) but is less so with average face value of new issues (38 percent).

20.When the log of real universal bank assets is regressed solely on a constant and a trend variable, the estimated coefficients are 0.073 for great banks, 0.063 for provincial banks. Part of this difference, of course, comes from moving two banks from the provincial bank category to the great bank category in the source (Deutsche Bundesbank, 1976). 21.The regressions use the turnover tax, or the tax on transfer of securities (averaging the various rates imposed by the split in 1900). The issue tax rate is calculated as the sum of domestic shares and debt rates. That variable yields insignificant results and is not reported (regression estimates are available from the author).

22.This topic is beyond the scope of the current paper. Interested readers may refer to Fohlin (2000a), Fohlin (1999), and the many references cited in those papers. Briefly, universal banking assets are not causally related, in a statistical sense, to real economic growth in Germany from 1883 to 1913.

23.One way to improve this proxy would be to estimate, for a sample of banks, the annual stream of profits stemming from brokerage transactions. This method would require finding a significant sample of banks reporting sufficient data for the years in question. Doing so represents a useful avenue for future research.

24.See Paul Milgrom and Nancy Stokey (1982). See also Andrew Lo and Jiang Wang (1998).

25.See, for example, the Handbook on the History of European Banks.

26.The English data are estimated using linear interpolation between the points given in Forrest Capie and Ghila RodrikBali (1982).

27.The German ratio is calculated using NNP from Hoffmann (1965), whereas the UK figures use GNP. The discrepancy means that if anything, the German ratio is overestimated compared to the UK ratio. See Fohlin (2001) for further details and comparisons of the German and British banking sectors. Edwards and Ogilvie (1996) also question the exceptionalism of the German universal system, while Baker and Collins (1999) revise the traditional view on English banks.

28.There are also possible political explanations. Rajan and Zingales (1999), for example, argue that the exigencies of War and preparation therefore, prompted many European governments to attempt to gain control over the financial system. By directly orchestrating concentration in banking, governments could direct financial matters with greater ease. These 
motives could hardly explain German stock exchange legislation of the 1890s, though this legislation is usually attributed to political motivations (that is, a response to agrarian protest at grain price declines in 1890-2). See Wiener (1905), Buss (1913), Meier (1993), and Schulz (1994).

29.On England and Wales (and the UK more generally), see Capie and Rodrik-Bali (1982).

30.See Fohlin (2000a).

31.Fohlin (2000b) estimates structural supply and demand equations for the German universal system in the 1884-1913 period to estimate the markups taken by the universal banks and therefore their market power. 
Table 1. Chronology of Economic and Legislative Events

\begin{tabular}{|c|c|c|c|c|c|}
\hline \multirow[t]{2}{*}{ Year } & \multirow[t]{2}{*}{ Date } & \multirow[t]{2}{*}{ Event } & \multicolumn{3}{|c|}{ Hypothesized effect on: } \\
\hline & & & $\begin{array}{l}\text { concentration } \\
\text { in universal } \\
\text { banking }\end{array}$ & $\begin{array}{l}\text { expansion of } \\
\text { universal } \\
\text { banks }\end{array}$ & $\begin{array}{c}\text { use of banks } \\
\text { over } \\
\text { securities } \\
\text { exchanges }\end{array}$ \\
\hline 1870 & & company law (requirements on issuing shares) & 8 & 8 & 8 \\
\hline 1884 & July 18 & $\begin{array}{l}\text { new company law: requirements on issuing } \\
\text { shares, protections for shareholders }\end{array}$ & 8 & 8 & \\
\hline 1885 & May 24 & institution of percentage tax on stock transfers & 8 & 8 & 8 \\
\hline 1891 & & fall in share prices & & & \\
\hline 1892 & Feb. 6 & $\begin{array}{l}\text { formation of stock exchange enquiry } \\
\text { commission }\end{array}$ & & 8 & \\
\hline 1893 & & $\begin{array}{l}\text { formation of Rhenish-Westphalian Coal } \\
\text { Syndicate }\end{array}$ & 8 & & \\
\hline 1894 & April 27 & $\begin{array}{l}\text { Imperial Stamp Act; doubling of stock transfer } \\
\text { tax }\end{array}$ & 8 & 8 & 8 \\
\hline \multirow[t]{2}{*}{1896} & June 22 & $\begin{array}{l}\text { stock exchange law: prohibition on futures } \\
\text { trading, waiting period }\end{array}$ & 8 & 8 & 8 \\
\hline & & $\begin{array}{l}\text { formalization of unified price system, tighter } \\
\text { requirements and broader liability on new } \\
\text { issues }\end{array}$ & & & 9 \\
\hline 1897 & & $\begin{array}{l}\text { formation of Rhenish-Westphalian Pig Iron } \\
\text { Syndicate }\end{array}$ & 8 & & \\
\hline \multirow[t]{2}{*}{1900} & June 14 & Imperial Stamp Act; further tax increases & 8 & 8 & 8 \\
\hline & & $\begin{array}{l}\text { closing of tax loopholes on compensatory } \\
\text { transactions }\end{array}$ & 9 & & 9 \\
\hline 1901 & & fall in share prices & & & \\
\hline 1907 & & fall in share prices & & & \\
\hline 1908 & & $\begin{array}{l}\text { new stock exchange law: reinstating futures } \\
\text { trading }\end{array}$ & & 9 & 9 \\
\hline
\end{tabular}

Note: blank cells indicate that the effect is indeterminate or the information is unknown.

Source: Discussion in text. 
Table 2. Determinants of Concentration in German Universal Banking

Top 5 bank assets as a share of total universal

and private bank assets
Top $5 \mathrm{~b}$ ank assets as a share of total universal bank assets

\begin{tabular}{|c|c|c|c|c|c|c|}
\hline \multirow[t]{2}{*}{ Real NNP } & 0.01 & 0.02 & 0.16 & 0.03 & 0.03 & 0.03 \\
\hline & 0.35 & 0.28 & 0.29 & 0.11 & 0.29 & 0.29 \\
\hline \multirow{2}{*}{$\begin{array}{l}\text { Average face value of } \\
\text { new dom estic shares in } \\
\text { Berlin (millions of } 1913 \\
\text { marks) }\end{array}$} & 38.52 & 34.63 & 36.92 & 35.32 & 55.99 & 55.99 \\
\hline & 0.08 & 0.08 & 0.07 & 0.08 & 0.16 & 0.16 \\
\hline \multirow{2}{*}{$\begin{array}{l}\text { Annual stock exchange } \\
\text { index }\end{array}$} & 0.06 & 0.05 & 0.06 & 0.08 & -0.03 & -0.03 \\
\hline & 0.10 & 0.21 & 0.11 & 0.03 & 0.65 & 0.65 \\
\hline \multirow{3}{*}{$\begin{array}{l}\text { Sub-period indicator } \\
\text { variable }\end{array}$} & 0.22 & 1.65 & 0.45 & & 3.92 & 0.002 \\
\hline & 0.87 & 0.17 & 0.71 & & 0.08 & 0.08 \\
\hline & (post-1892) & (post-1894) & (post-1896) & & (post-1894) & (post-1894*yr) \\
\hline \multirow[t]{2}{*}{ Turnover tax rate } & & & & 70.29 & & \\
\hline & & & & 0.09 & & \\
\hline \multirow[t]{2}{*}{ Year } & 0.52 & 0.47 & 0.50 & 0.25 & -0.20 & -0.20 \\
\hline & 0.01 & 0.01 & 0.01 & 0.25 & 0.54 & 0.53 \\
\hline \multirow[t]{2}{*}{ Constant } & -977.16 & -875.53 & -931.06 & -476.18 & 397.24 & 400.61 \\
\hline & 0.01 & 0.01 & 0.01 & 0.25 & 0.50 & 0.50 \\
\hline Number of observations & 29 & 29 & 29 & 29 & 29 & 29 \\
\hline $\mathrm{F}$ & 18.80 & 20.94 & 19.29 & 29.02 & 3.40 & 3.40 \\
\hline$($ Prob $>$ F $)$ & 0.00 & 0.00 & 0.00 & 0.00 & 0.02 & 0.02 \\
\hline $\operatorname{adj} . R^{2}$ & 0.77 & 0.78 & 0.77 & 0.83 & 0.30 & 0.30 \\
\hline $\begin{array}{l}\text { D-W statistic } \\
\text { (transformed) }\end{array}$ & 1.60 & 1.60 & 1.54 & 1.64 & 1.70 & 1.70 \\
\hline \multirow[t]{2}{*}{ Rho } & 0.70 & 0.70 & 0.79 & 0.65 & 0.54 & 0.54 \\
\hline & 0.00 & 0.00 & 0.00 & 0.00 & 0.00 & 0.00 \\
\hline
\end{tabular}

Note: P-values of t-tests (two-sided) are entered in italics below coefficient estimates. Models are estimated using Cochrane-Orcutt regression. The fin al row of the table gives the resulting ser ial correlation estimate.

Source: Concentration ratios calculated from Deutsche Bundesbank (1976), Saling s (various years), Handbuch der deutschen Aktiengesellschaften (various years), and Goldsmith (1969); NNP from Hoffmann (1965); stock issues from Wetzel (1996); tax rates from Gömmel (1992); stock price index from Gielen (1994). 
Table 3. Determinants of Growth in German Universal Banking

\begin{tabular}{|c|c|c|c|c|c|c|c|c|}
\hline & 1 & 2 & 3 & 4 & 5 & 6 & 7 & 8 \\
\hline \multirow[t]{2}{*}{ Real NNP } & 0.001 & 0.001 & 0.001 & 0.001 & 0.001 & 0.001 & 0.001 & 0.001 \\
\hline & 0.07 & 0.08 & 0.06 & 0.07 & 0.08 & 0.06 & 0.12 & 0.02 \\
\hline \multirow{2}{*}{$\begin{array}{l}\text { New domestic shares, Berlin (total face } \\
\text { value, millions of } 1913 \text { marks) }\end{array}$} & 0.02 & 0.02 & 0.02 & 0.02 & 0.02 & 0.02 & 0.02 & 0.02 \\
\hline & 0.00 & 0.00 & 0.00 & 0.00 & 0.00 & 0.00 & 0.00 & 0.00 \\
\hline \multirow[t]{3}{*}{ Sub-period indicator variable } & -0.02 & 0.02 & 0.06 & 0.00 & 0.00 & 0.00 & 0.00 & \\
\hline & 0.66 & 0.69 & 0.22 & 0.66 & 0.69 & 0.22 & 0.52 & \\
\hline & post-1892 & post-1894 & post-1896 & post-1892*yr & post-1894*yr & post-1896*yr & post- $1900 * y r$ & \\
\hline \multirow[t]{2}{*}{ Turnover tax rate } & & & & & & & & 3.09 \\
\hline & & & & & & & & 0.05 \\
\hline \multirow[t]{2}{*}{ Year } & 0.06 & 0.05 & 0.05 & 0.06 & 0.05 & 0.05 & 0.05 & 0.05 \\
\hline & 0.00 & 0.00 & 0.00 & 0.00 & 0.00 & 0.00 & 0.00 & 0.00 \\
\hline \multirow[t]{2}{*}{ Constant } & 101.52 & -99.63 & -94.80 & -101.54 & -99.61 & -94.74 & -99.09 & -82.68 \\
\hline & 0.00 & 0.00 & 0.00 & 0.00 & 0.00 & 0.00 & 0.00 & 0.00 \\
\hline Number of observations & 29 & 29 & 29 & 29 & 29 & 29 & 29 & 29 \\
\hline \multirow{2}{*}{$\begin{array}{l}\mathrm{F} \\
(\text { Prob }>\mathrm{F})\end{array}$} & 129.95 & 137.14 & 175.6 & 129.9 & 137.22 & 176.00 & 185.41 & 300.19 \\
\hline & 0.00 & 0.00 & 0.00 & 0.00 & 0.00 & 0.00 & 0.00 & 0.00 \\
\hline adj. $R^{2}$ & 0.95 & 0.95 & 0.96 & 0.96 & 0.95 & 0.96 & 0.96 & 0.98 \\
\hline \multirow{2}{*}{$\begin{array}{l}\text { D-W statistic } \\
\text { transformed }\end{array}$} & 0.80 & 0.69 & 0.83 & 0.80 & 0.69 & 0.83 & 1.37 & 1.03 \\
\hline & 1.92 & 2.00 & 1.96 & 1.92 & 2.00 & 1.96 & 1.98 & 1.99 \\
\hline \multirow[t]{2}{*}{ Rho } & 0.68 & 0.67 & 0.64 & 0.68 & 0.67 & 0.64 & 0.62 & 0.54 \\
\hline & 0.00 & 0.00 & 0.00 & 0.00 & 0.00 & 0.00 & 0.00 & 0.00 \\
\hline
\end{tabular}

Note: Dependent variable is the natural log of real joint-stock universal bank assets. P-values of t-tests (two-sided) are entered in italics below coefficient estimates.

Source: Total assets calculated from Deutsche Bundesbank (1976) and Goldsmith (1969); NNP from Hoffmann (1965); stock issues from Wetzel (1996); tax rates from Gömmel (1992), 
Table 4. Determinants of Universal Bank Turnover/Berlin Exchange Turnover

\begin{tabular}{|c|c|c|c|c|c|c|c|c|c|c|}
\hline & 1 & 2 & 3 & 4 & 5 & 6 & 7 & 8 & 9 & 10 \\
\hline Annual stock & -0.02 & -0.02 & -0.02 & -0.02 & -0.02 & -0.02 & -0.02 & -0.02 & -0.02 & -0.02 \\
\hline exchange index & 0.06 & 0.06 & 0.05 & 0.06 & 0.06 & 0.06 & 0.05 & 0.06 & 0.01 & 0.05 \\
\hline Real NNP per & 165.03 & 119.63 & 122.98 & 128.72 & 164.99 & 119.61 & 122.98 & 128.68 & 24.19 & 115.06 \\
\hline capita & 0.20 & 0.30 & 0.05 & 0.26 & 0.20 & 0.30 & 0.28 & 0.26 & 0.78 & 0.33 \\
\hline \multirow[t]{2}{*}{ Year } & 0.06 & 0.05 & 0.05 & 0.06 & 0.06 & 0.05 & 0.054 & 0.06 & 0.15 & 0.06 \\
\hline & 0.03 & 0.04 & 0.06 & 0.06 & 0.03 & 0.05 & 0.055 & 0.06 & 0.00 & 0.10 \\
\hline \multirow[t]{2}{*}{ Constant } & -104.31 & -99.32 & -101.23 & -111.86 & -104.53 & -99.23 & -101.18 & -111.86 & -273.96 & -113.78 \\
\hline & 0.02 & 0.04 & 0.05 & 0.06 & 0.02 & 0.04 & 0.05 & 0.06 & 0.00 & 0.10 \\
\hline Sub-period & -0.23 & 0.07 & 0.02 & 0.06 & -0.00 & 0.00 & 0.00 & -0.00 & & \\
\hline \multirow[t]{2}{*}{ indicator } & 0.41 & 0.80 & 0.96 & 0.06 & 0.41 & 0.80 & 0.96 & 0.78 & & \\
\hline & (post-1892) & (post-1894) & (post-1896) & (post-1900) & (post-1892*yr) & (post-1894*yr) & (post-1896*yr) & (post-1900*yr) & & \\
\hline Turnover/issue & & & & & & & & & -0.34 & -2.14 \\
\hline \multirow[t]{2}{*}{ tax rate } & & & & & & & & & 0.00 & 0.82 \\
\hline & & & & & & & & & (issue) & (turn-over) \\
\hline \# obs & 28 & 28 & 28 & 28 & 28 & 28 & 28 & 28 & 28 & 28 \\
\hline $\mathrm{F}$ & 6.89 & 5.86 & 5.98 & 5.79 & 6.88 & 5.86 & 5.98 & 5.79 & 11.31 & 6.02 \\
\hline$($ Prob > F ) & $(0.001)$ & $(0.002)$ & $(0.002)$ & $(0.002)$ & $(0.000)$ & $(0.002)$ & $(0.002)$ & $(0.002)$ & $(0.000)$ & $(0.002)$ \\
\hline $\operatorname{adj} . R^{2}$ & 0.47 & 0.42 & 0.42 & 0.42 & 0.47 & 0.42 & 0.42 & 0.42 & 0.60 & 0.43 \\
\hline D-W statistic & 1.03 & 1.04 & 1.04 & 1.04 & 1.03 & 1.04 & 1.04 & 1.04 & 0.84 & 1.03 \\
\hline transformed & 1.41 & 1.40 & 1.40 & 1.40 & 1.41 & 1.40 & 1.40 & 1.40 & 1.52 & 1.41 \\
\hline \multirow[t]{2}{*}{ Rho } & 0.51 & 0.55 & 0.54 & 0.56 & 0.51 & 0.55 & 0.54 & 0.56 & 0.72 & 0.54 \\
\hline & 0.01 & 0.00 & 0.00 & 0.00 & 0.01 & 0.00 & 0.00 & 0.00 & 0.00 & 0.00 \\
\hline
\end{tabular}

Sources: Turnover ratio calculated from Eistert (1970) and Wetzel (1996); stock exchange index from Gielen (1994); NNP from Hoffmann (1965); tax rates from Gömmel (1992). 
Table 5. Banking Industry Structure: Germany and the U.K.

\begin{tabular}{|c|c|c|c|c|c|c|}
\hline & \multicolumn{2}{|c|}{1890} & \multicolumn{2}{|c|}{1900} & \multicolumn{2}{|c|}{1910} \\
\hline & Germany & U.K. & Germany & U.K. & Germany & U.K. \\
\hline Thousands of people/bank & 302 & $\begin{array}{c}116 \\
(285)\end{array}$ & 268 & $\begin{array}{c}204 \\
(323)\end{array}$ & 221 & $\begin{array}{c}374 \\
(552)\end{array}$ \\
\hline $\begin{array}{l}\text { Average assets/bank } \\
\text { (millions } 1913 \text { dollars) }\end{array}$ & 9.4 & 27.8 & 15.6 & 43.3 & 23.3 & 73.7 \\
\hline $\begin{array}{l}\text { Five-firm asset concentration } \\
\text { ratio }\end{array}$ & $\begin{array}{c}17.4 \\
(33.9)\end{array}$ & $\begin{array}{c}21 \\
(26.5)\end{array}$ & $\begin{array}{c}24.7 \\
(37.2)\end{array}$ & $\begin{array}{l}25.5 \\
(31)\end{array}$ & $\begin{array}{c}30.8 \\
(38.8)\end{array}$ & $\begin{array}{l}35.5 \\
(43)\end{array}$ \\
\hline $\begin{array}{l}\text { Ten-firm asset concentration } \\
\text { ratio }\end{array}$ & $\begin{array}{c}28.8 \\
(56.3)\end{array}$ & $\begin{array}{c}32 \\
(38)\end{array}$ & $\begin{array}{l}33.3 \\
(50)\end{array}$ & $\begin{array}{l}41 \\
(46.3)\end{array}$ & $\begin{array}{c}43.5 \\
(54.8)\end{array}$ & $\begin{array}{l}56 \\
(64.7)\end{array}$ \\
\hline
\end{tabular}

Note: Number of banks in parentheses are estimates using Shepard (1971). German figures exclude private banks. Concentration ratios in parentheses, for Germany, exclude estimated private bank assets; and, for the U.K., include only England and Wales. The concentration ratios estimated for the U.K. by Capie and Rodrik-Bali include private banks. See discussion in text.

Sources: Main source for number of U.K. banks is Capie and Webber (1985). Figures in parentheses are estimates using number of banks from Shepard (1971). German bank ratios estimated from Deutsche Bundesbank (1976), Saling's (various years), Handbuch der deutschen Aktiengesellschaften (various years), and Goldsmith (1969) 


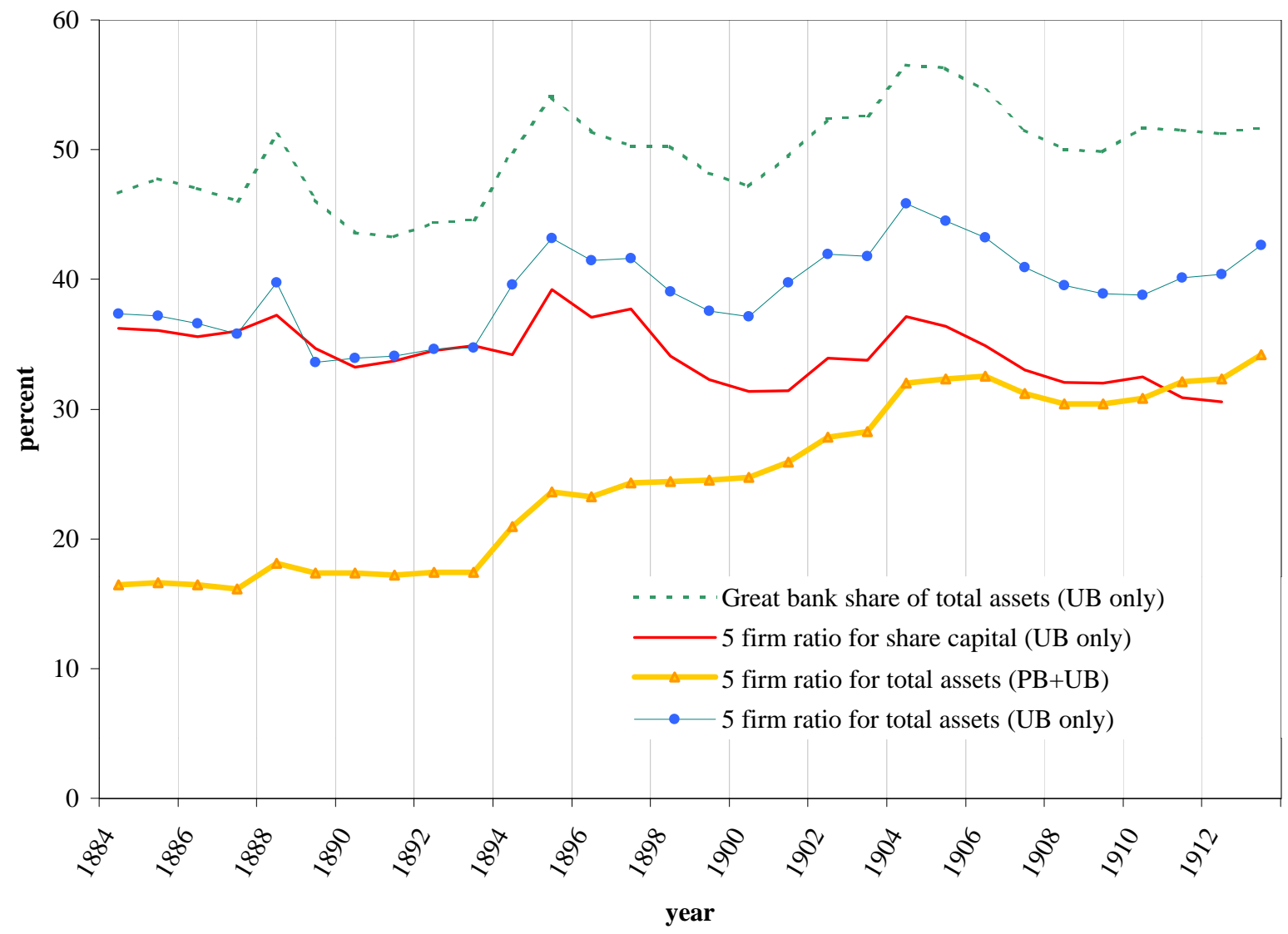

Figure 1. Measures of Universal Banking Concentration in Germany, 1884-1913

Sources: calculated from Deutsche Bundesbank (1976), Saling's (various years), Handbuch der deutschen Aktiengesellschaften (various years), and Goldsmith (1969). 


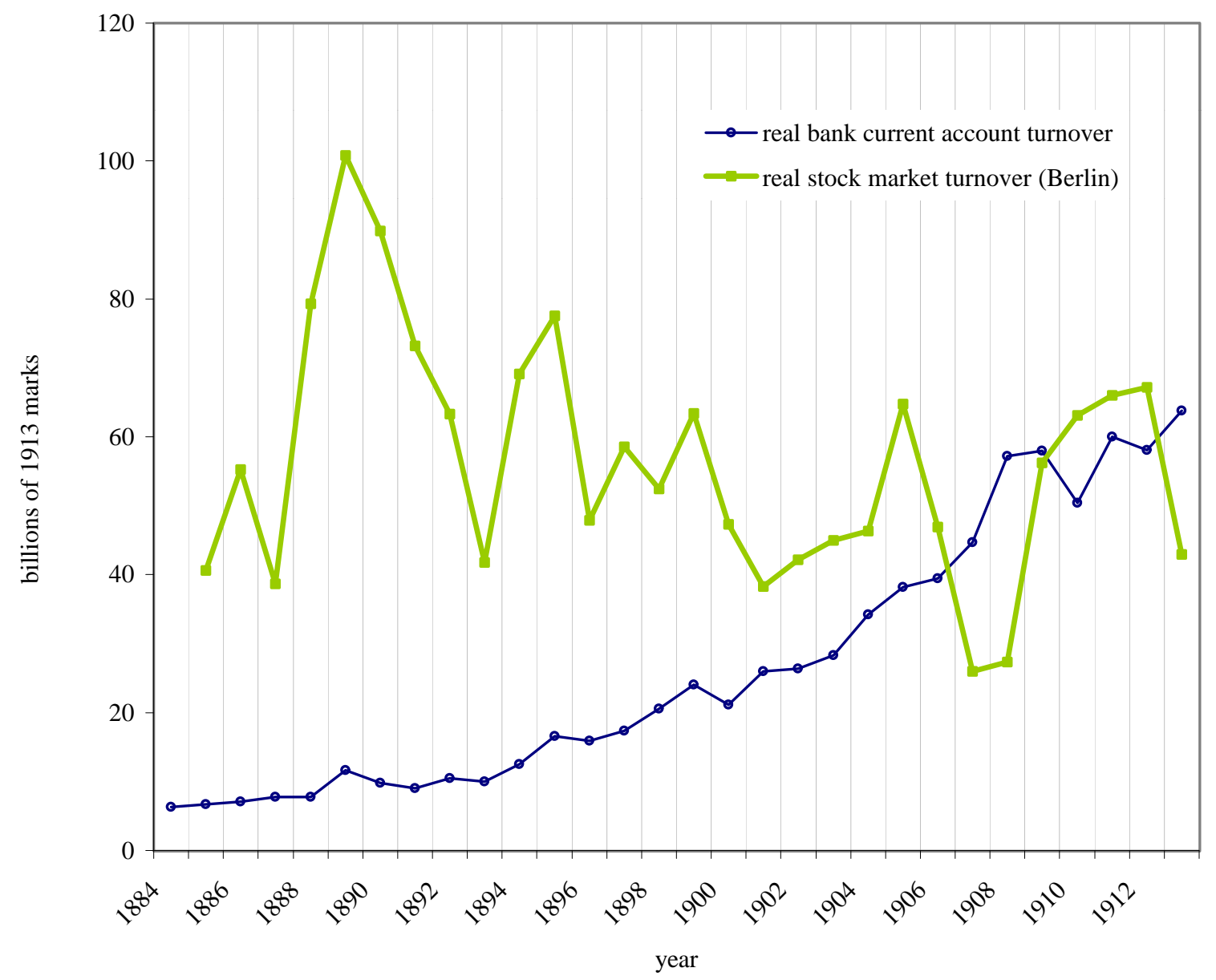

Figure 2. Real Turnover in German Universal Banks and Stock Markets, 1884-1913

Sources: Eistert (1970) and Wetzel (1996). 


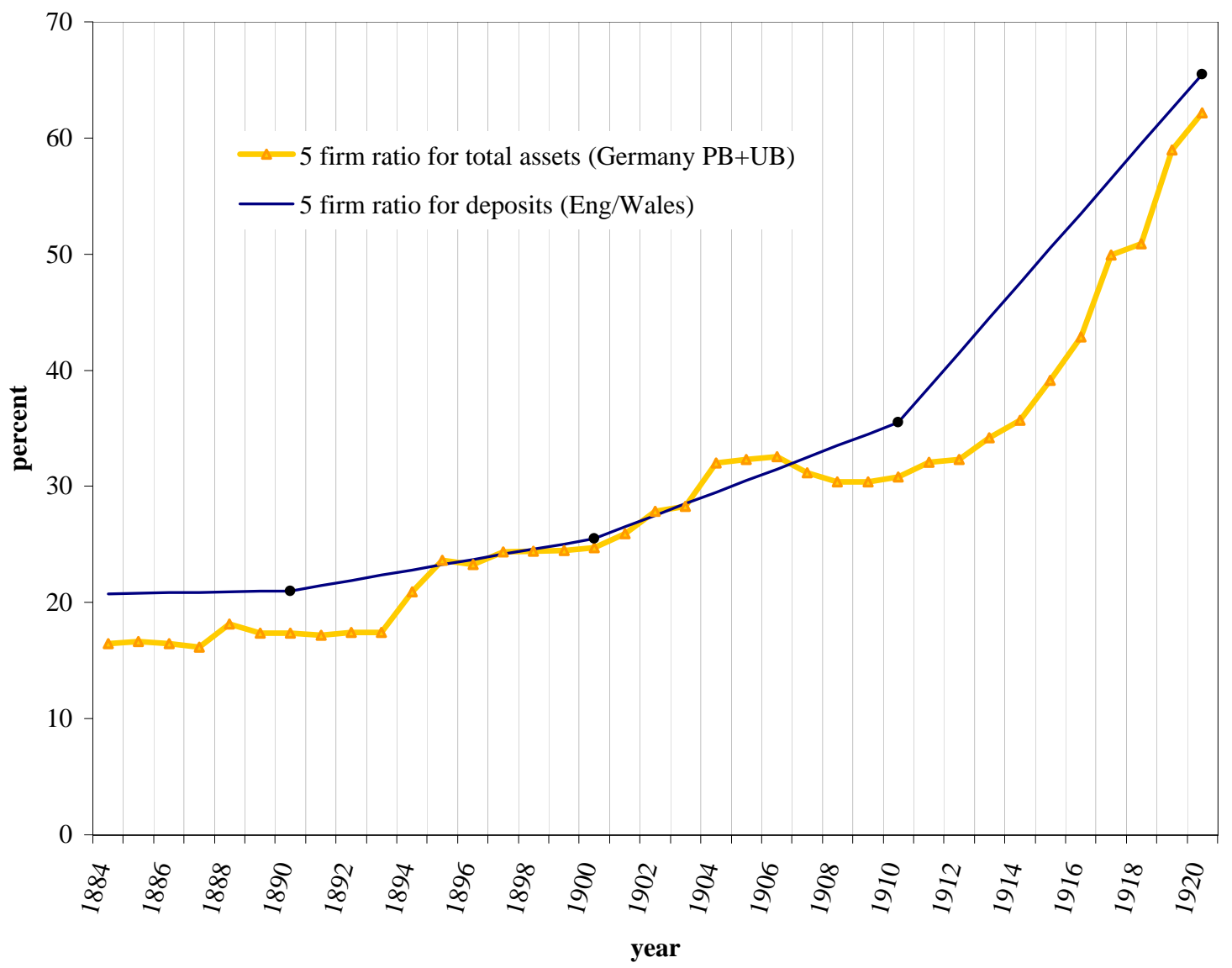

Figure 3. Banking Concentration in Germany and England/Wales, 1884-1920

Sources: calculated from Deutsche Bundesbank (1976), Saling's (various years), Handbuch der deutschen Aktiengesellschaften (various years), Goldsmith (1969), and Capie and Rodrik-Bali (1982). 


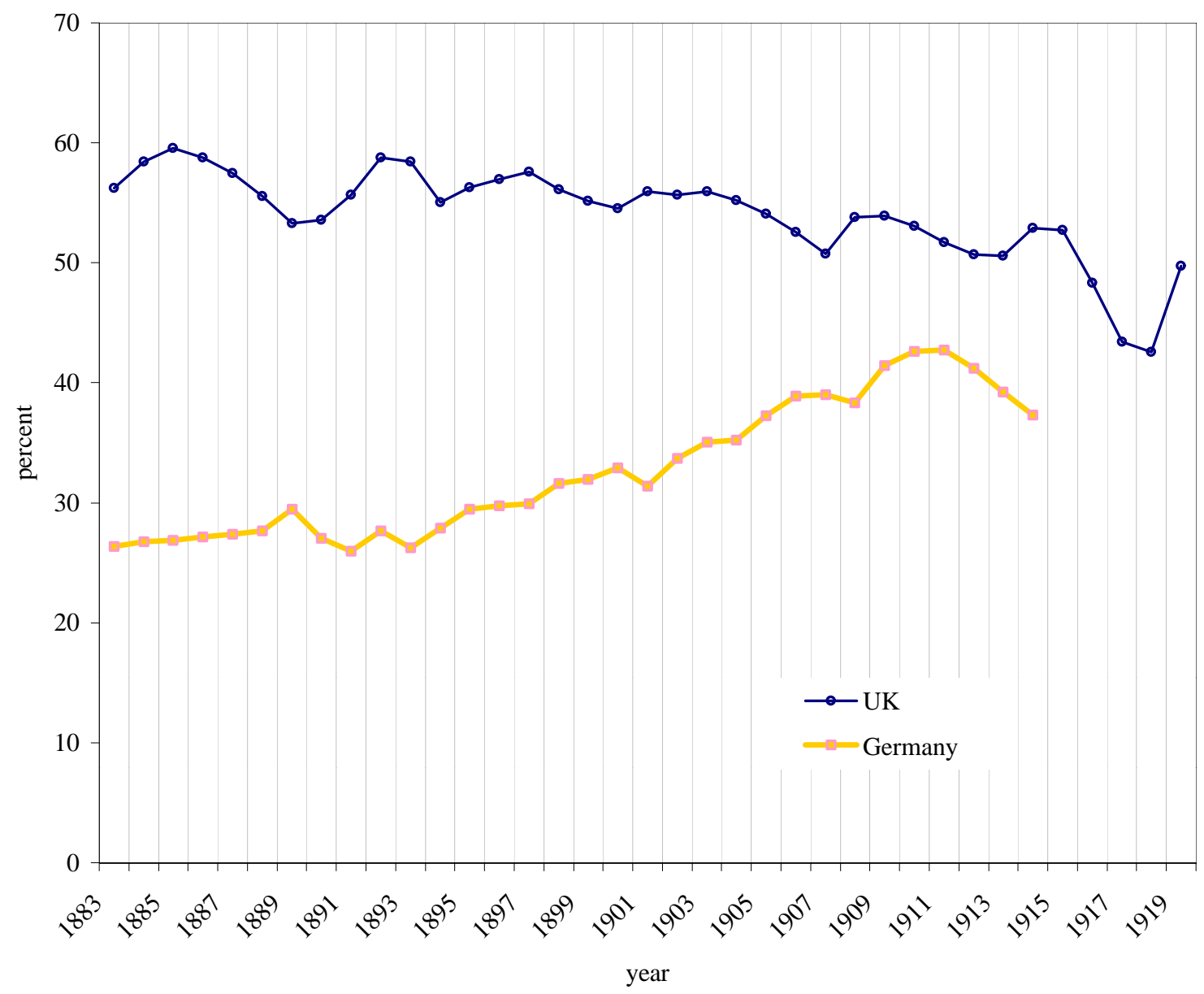

Figure 4. Total Universal/Deposit Bank Assets as a Share of National Product in Germany and the UK, 1883-1920

Sources : Capie and Webber (1985), Deutsche Bundesbank (1976), and Goldsmith (1969). 